\title{
Treatment of Atherosclerotic Disease of the Femoral Artery: Randomized Controlled Trials and Meta-Analyses. Should You Be Sceptical?
}

\author{
Raymond Englund \\ St George Private Hospital, Kogarah, Sydney \\ Email:renglund@ihug.com.au
}

How to cite this paper: Englund, R. (2019) Treatment of Atherosclerotic Disease of the Femoral Artery: Randomized Controlled Trials and Meta-Analyses. Should You Be Sceptical? Surgical Science, 10, 235-254. https://doi.org/10.4236/ss.2019.107026

Received: May 27, 2019

Accepted: July 27, 2019

Published: July 30, 2019

Copyright (อ 2019 by author(s) and Scientific Research Publishing Inc. This work is licensed under the Creative Commons Attribution International License (CC BY 4.0).

http://creativecommons.org/licenses/by/4.0/

\section{(c) (i) Open Access}

\begin{abstract}
A narrative review of the data provided by Randomised Controlled clinical trials and meta-analyses was undertaken to assess how much reliance a clinician could place on these in selecting a treatment for patients with disease of the Femoral artery. An attempt was made to detect and review every clinical trial and meta-analysis published on treatments relating to disease of the femoral artery but not relating to drug treatment. Disease of the femoral artery in $>65$ years age group occurs in approximately $20 \%$ of the population but symptomatology was present in $<2 \%$. Associated morbidity was high and the 5-year mortality rate was $>40 \%$. In almost all trials the predominant $(>90 \%)$ indication for treatment was intermittent claudication. In this setting, clinical benefit was limited and did not extend beyond 12 months. Mortality, from co-morbidities was high. The Basil Trial was the only one to examine intervention for critical limb ischemia. The results for Bypass surgery and Percutaneous transarterial balloon angioplasty (PTA) were equivalent. There is little evidence to support the use of PTA or stenting other than in the treatment of patients with critical limb ischemia.
\end{abstract}

\section{Keywords}

Femoral Artery, Stent (Nitinol, Drug-Eluting, Covered), Percutaneous Balloon Angioplasty, Drug Eluting Balloons, Randomised Controlled Trials, Meta-Analyses, Intermittent Claudication, Critical Limb Ischemia, Patency, Clinical Benefit

\section{Background}

Atherosclerotic disease of the femoral Artery is a marker for the presence of systemic atherosclerotic disease. It may manifest in any one of 3 ways; asympto- 
matic, as intermittent claudication (IC-the disability of being able to walk only a limited distance before the development of calf pain induces the necessity of stopping to rest before being able to carry on usually for a similar distance) and as critical limb ischemia (CLI) evidenced by rest pain, ulceration or gangrene.

Diehm C, Schuster A, Allenberg JR et al. [1] reported on 6880, unselected patients, older than 65 years of age in the German Epidemiological Trial. In this cross-sectional study 344 general practitioners measured bilateral Doppler ultrasound ankle brachial systolic pressure Indices (ABSPI) bilaterally, recorded history, physical examination, and the WHO questionnaire on Claudication. Males accounted for $42 \%$ of the cohort, $19.8 \%$ had low ABPSI (indicating atherosclerotic disease-PAD) and $16.8 \%$ were women with reduced ABSPI and PAD. Patients with PAD had Odds Ratio (OR) of diabetes $\mathrm{x} 1.8$, hypertension $\mathrm{x}$ 2.2, lipid disorders $\times 1.3$, cerebrovascular event $\times 1.8$ and any cardiovascular event x 1.8.

Similarly, Meijer WT, Hoes AW, Rutgers D et al. [2], in the Rotterdam study, investigated 7715 patients over 55 years of age (40\% men, 60\% women) and found the prevalence of PAD to be $19.1 \%$, but symptoms of IC were present in only $1.6 \%$ of the study population (men-2.2\%, women-1.2\%). When PAD was detected, $6.8 \%$ reported IC. This study highlighted that the increased incidence of PAD in the elderly was not associated with frequent symptomatology.

Therefore, question arises as to when PAD in the femoral artery should be treated and what form should this treatment take. It is clear from the quoted studies that the co-morbidities of hypertension, diabetes, lipid disorders and smoking should be addressed as baseline management of any patient with peripheral vascular disease.

\section{Methodology}

The format of this research was by narrative review. This study was not a meta-analysis or systematic review but was designed to include information that would have been excluded by these techniques. Figure 1 shows the Flow diagram of literature selection process.

I formulated research questions such as "what is the natural history of atherosclerotic disease of the femoral artery?", "supervised exercise therapy and intermittent claudication", "trials of supervised exercise therapy compared to

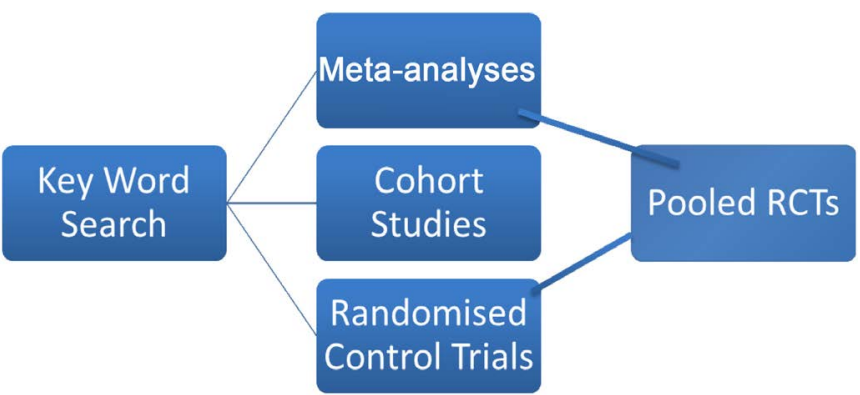

Figure 1. Flow diagram of literature selection process. 
intervention", "treatment of atherosclerotic disease of the femoral artery by percutaneous balloon angioplasty (PTA) and stenting", "drug eluting balloons (DEB) in PTA and drug eluting stents and the femoral artery" and cross referenced these with clinical trials and meta-analyses. Within each question, the initial objective was to identify all published meta-analyses that addressed the given research question. A meta-analysis that addressed the given research then became a source of references with respect to that research question. Studies used in the given meta-analysis were obtained. Where possible studies that were excluded from the meta-analysis were also obtained. Cochrane reviews were particularly useful in this respect because they contained a complete list of references that were not included in the ultimate review.

The data extraction method used was by searching for keywords PTA, DEB, DES, balloon angioplasty, covered stent, standardized exercise programs and peripheral artery disease. These keywords were cross reference with disease of the femoral artery and superficial femoral artery. Search engines used include PUBMED, Clinical Knowledge Network, Medline and The Cochrane Review.

When those studies from meta-analysis had been obtained, they then became a source further to obtain references. The bulk of this work was performed by hand and requests to libraries for reprints of publications. Reference was made to trials registry and when a trial was identified an attempt was made to obtain the published results of that trial. In some cases, references to abstracts from clinical meetings are obtained from the reference section of a publication. Where possible a copy of the abstract was obtained.

References that were excluded were those that pertained to treatment of atherosclerotic disease of the aortoiliac or infra-popliteal segments of the vascular system where data relating to the femoropopliteal segment could not be separated.

Analysis of the data obtained through the above process was then cross-tabulated in chronological order. Data points of particular interest were year of publication and authors. This produced a number of cases of double, complete and fragmentary publication and the publication of some trial results outside the ultimate declaration of trial results. The type of study that had been conducted, the number of patients at recruitment and number of patients on which the analysis was made and the type of intervention was also noted. The trial endpoints and the stated conclusions of the trial investigators were also included in these cross-referencing tables. Finally, the involvement of industry in the conduct of the trial and declared conflict of interests of authors was noted. What soon became obvious was that while financial conflict of interest was readily declared, few authors recognised the possibility of intellectual conflicts of interest.

\section{Supervised Exercise Training for Intermittent Claudication}

Hobbs SD, Bradbury AW [3] outlined the difficulties associated with conducting 
RCT's of supervised exercise training versus no treatment. However, some researchers managed to overcome these problems. Ratcliff DA et al. [4] demonstrated that clinical benefit of supervised exercise training gained at 12 weeks could be sustained for up to 3 years. This was not a RCT. An update of the Cochrane Data Base [5] in 2017 came to the following conclusions based on 32 studies involving 1835 patients: maximum walking distance could be significantly improved from 82.11 meters to 92.48 in studies where no exercise was compared to exercise treatment, improvements were seen for up to 2 years. Exercise provided no benefit for outcomes of amputation or mortality. The authors commented on significant heterogeneity between trials. Although this review found statistical benefit and cost-effectiveness for supervised exercise therapy, one could reasonably question what lifestyle benefit patients would gain from this small improvement in walking distance gained by supervised exercise therapy. Mazari et al. [6], in a study comparing PTA to exercise therapy, RCT for claudication patients, showed that PTA conferred a benefit related to physical function and bodily pain but no benefit for general overall health and no benefit beyond 12 months.

Table 1 lists a number of RCT's comparing PTA to supervised exercise therapy and one trial of PTA to SEP alone and PTA combined with SEP. These trials

Table 1. Supervised exercise therapy SET vs. PTA.

\begin{tabular}{|c|c|c|c|c|c|c|}
\hline Year & Author & Journal & $\begin{array}{l}\text { PTA } \\
\text { (n) }\end{array}$ & $\begin{array}{l}\text { SET } \\
\text { (n) }\end{array}$ & $\begin{array}{c}\text { Bibliographic } \\
\text { Number }\end{array}$ & Conclusions \\
\hline 1990 & $\begin{array}{l}\text { Creasy } \\
\text { TS }\end{array}$ & $\begin{array}{l}\text { Eur J Vasc } \\
\text { Surg }\end{array}$ & 20 & 16 & [8] & $\begin{array}{l}\text { ABSPI improved with } \\
\text { PTA but exercise was } \\
\text { better for walking distance } \\
\text { at } 12 \text { months }\end{array}$ \\
\hline 1996 & $\begin{array}{l}\text { Perkins } \\
\text { JMT }\end{array}$ & $\begin{array}{l}\text { Eur J Vas } \\
\text { Endovas } \\
\quad \text { Surg }\end{array}$ & 30 & 26 & [9] & $\begin{array}{l}\text { Exercise training confers } \\
\text { greater benefit in } \\
\text { claudication over PTA }\end{array}$ \\
\hline 1997 & $\begin{array}{l}\text { Whyman } \\
\text { MR }\end{array}$ & J Vasc Surg & 30 & 32 & {$[10][11]$} & No difference at 2 years \\
\hline 2007 & $\begin{array}{c}\text { Nylaende } \\
\text { M }\end{array}$ & $\begin{array}{l}\text { Eur J Vas } \\
\text { Endovas } \\
\quad \text { Surg }\end{array}$ & 28 & 28 & {$[12]$} & $\begin{array}{l}\text { Home-based exercise/not } \\
\text { supervised. Benefit for } \\
\text { PTA plus Optimal medical } \\
\text { therapy }\end{array}$ \\
\hline 2008 & $\begin{array}{l}\text { MIMIC } \\
\text { Trial }\end{array}$ & $\begin{array}{l}\text { Eur J Vas } \\
\text { Endovas } \\
\text { Surg }\end{array}$ & 48 & 45 & [13] & $\begin{array}{l}\text { In fem-pop group short } \\
\text { term benefit for ABSPI but } \\
\text { not quality of life }\end{array}$ \\
\hline 2009 & Spronk & Radiology & 76 & 75 & {$[14]$} & $\begin{array}{l}\text { Any initial advantage for } \\
\text { PTA lost at } 6 \text { months }\end{array}$ \\
\hline 2012 & Mazari & BJS & 60 & 60 & {$[15]$} & $\begin{array}{l}\text { Included } \mathrm{n}=58 \text { who had } \\
\text { both PTA }+ \text { SEP, no } \\
\text { quality of life } \\
\text { improvement for any } \\
\text { group. PTA \& SEP } \\
\text { equivalent }\end{array}$ \\
\hline
\end{tabular}


dealt with patients in whom the focal arterial disease was in the femoral artery. There are a number of trials that include disease in the aortoiliac segment which have not been included in this table. However, Aherne $\mathrm{T}$ et al. [7] have conducted a meta-analysis of 11 RCT's (969 patients) comparing SET with intervention, but with disease involving multiple levels. Their conclusion was that all trials should include SET and optimal medical therapy. As will be outlined below this is a recommendation that is rarely included in most interventional RCT trials.

\section{PTA (with Stent Bailout) versus Routine Stenting}

There are six meta-analyses which examine this question covering RCT's between 1997 and 2014. Essentially all came to the same conclusion; that there is no durable benefit for routine stenting and that any initial benefit is lost within 12 months.

None of the RCT's contains control groups of optimal medical treatment and SET. The number of RCT's in each meta-analysis varies depending on the inclusion criteria chosen by the authors. There is a suggestion of double publishing among RCT's and double counting in the meta-analyses. Taken together they produce little evidence to support either PTA or stenting of the femoral artery particularly in patients suffering from IC. Table 2(a) lists these meta-analyses while Table 2(b) is a list of references for RCT's included in the meta-analyses of Table 2(a). At Least 2 of these meta-analyses have significant contributions of data from cohort studies, the remainder relies entirely on RCT's. The most reliable appears to be the Cochrane Meta-analysis from 2014 which took data from 11 trials and 1387 patients. Their conclusions were that any initial advantage for stenting routinely was lost within 24 months. Further, there was no improvement in quality of life from a physical or mental viewpoint. This meta-analysis included both patients with intermittent claudication and critical limb ischemia but excluded trials of new technology such as drug eluting balloons (DEB) and stents (DES).

The last meta-analysis included in Table 2(a) is performed by Antonopoulos et al. [88]. This meta-analysis compared 11 treatments for femoral artery occlusive disease. The authors selected 33 studies to compare primary patency and binary restenosis at 12 months follow up. They concluded that DES and bypass surgery maintain roles as the principal intervention. The data for DES was based on 1 study [68]. The data for bypass surgery was based on 3 studies [72] [73] [89]. One trial [72] had been terminated prematurely with 44 patients recruited because an interim analysis had shown that only $4 \%$ of lesions were amenable to the study. Another study [73] concluded that percutaneous treatment with stent graft was comparable to bypass revascularization at 12 months. The last study [72] made the following statement "Despite 18 participating centres, only 56 patients were randomized to PTA or bypass surgery".

The meta-analysis in question included only 200 patients, this was less than 
Table 2. Meta-analysis of trials of PTA vs. stent.

(a)

\begin{tabular}{|c|c|c|c|c|c|}
\hline Journal & Author & $\begin{array}{l}\text { Study } \\
\text { Period }\end{array}$ & $\begin{array}{c}\text { \# of } \\
\text { Studies }\end{array}$ & Results & Conclusion \\
\hline $\begin{array}{l}\text { J. Radiology } \\
\text { (2002) }\end{array}$ & $\begin{array}{l}\text { Muradin, } \\
\text { GS [16] }\end{array}$ & $1993-2000$ & 19 & $\begin{array}{l}\text { PTA }=923 \text {, Stent }=473 . \\
\text { Claudication results depended } \\
\text { on lesion type. CLI results were } \\
\text { independent of lesion types. } \\
\text { Results were similar in both } \\
\text { lesion types. }\end{array}$ & $\begin{array}{l}\text { Funnel plot } \\
\text { asymmetrical. } \\
\text { Cohort study } \\
\text { used for } \\
\text { analysis. }\end{array}$ \\
\hline $\begin{array}{l}\text { J. Vasc Intev } \\
\text { Radiol (2008) }\end{array}$ & $\begin{array}{c}\text { YaJun } \\
{[17]}\end{array}$ & 1999-2007 & 7 & $\begin{array}{l}\text { PTA and stent placement } \\
\text { better } 6 / 12 \text { patency than PTA } \\
\text { alone with no difference after } \\
\text { this time }\end{array}$ & $\begin{array}{l}\text { Initial benefit } \\
\text { for PTA and } \\
\text { stent lost at } 6 \\
\text { months }\end{array}$ \\
\hline $\begin{array}{l}\text { J Vasc Surg } \\
\text { (2008) }\end{array}$ & $\begin{array}{l}\text { Mwipatayi } \\
{[18]}\end{array}$ & $2000-2007$ & 24 & $\begin{array}{l}\text { PTA }=452 \text {, stent }=482 . \\
\text { Patency no different } \\
\text { between the groups. }\end{array}$ & $\begin{array}{l}\text { At } 1 \text { year no } \\
\text { difference } \\
\text { between groups } \\
\text { for patency }\end{array}$ \\
\hline $\begin{array}{c}\text { European } \\
\text { Heart Journal } \\
\text { (2009) }\end{array}$ & $\begin{array}{c}\text { Kasapis } \\
{[19]}\end{array}$ & $1997-2007$ & 10 & $\begin{array}{l}\text { Stent }=274 \text {, PTA with } \\
\text { provisional stent }=718 . \\
\text { Immediate technical failure } \\
\text { higher in PTA group. } \\
\text { CLI }<10 \% \text { of patients. }\end{array}$ & $\begin{array}{l}\text { No difference in } \\
\text { TVR. Similar } \\
\text { amputation rate. }\end{array}$ \\
\hline $\begin{array}{l}\text { J Vasc Surg } \\
(2010)\end{array}$ & $\begin{array}{c}\text { Perio } \\
{[20]}\end{array}$ & 1997-2007 & 19 & $\begin{array}{l}\text { cohort studies used in } \\
\text { analysis }\end{array}$ & $\begin{array}{l}\text { 1-year patency } \\
\text { for stent } \\
\text { placement or } \\
\text { PTA alone no } \\
\text { difference. } \\
\text { Studies high } \\
\text { degree of } \\
\text { heterogeneity }\end{array}$ \\
\hline $\begin{array}{c}\text { Cochrane } \\
\text { Data Base } \\
(2014)\end{array}$ & $\begin{array}{c}\text { Chowdhury } \\
{[21]}\end{array}$ & 2014 & 11 & $\begin{array}{l}\text { Benefit of PTA and stent } \\
\text { lost at } 12 \text {-months. }\end{array}$ & $\begin{array}{l}\text { No long-term } \\
\text { difference } \\
\text { between groups }\end{array}$ \\
\hline
\end{tabular}

(b)

\begin{tabular}{ccl}
\hline Author & Bibliography Reference & \multicolumn{1}{c}{ Comment } \\
\hline Muradin & {$[22]-[37]$} & $\begin{array}{l}\text { Double counting } \\
\text { due to double } \\
\text { publishing }\end{array}$ \\
Yajun & {$[38]-[44]$} & $\begin{array}{l}\text { Potential double } \\
\text { count }\end{array}$ \\
Mwipatayi & {$[24][38][41][42][43][45][46][47]$} & \\
Kasapsis & {$[22][24][38][40][41][45][46][48]$} & \\
Perio & {$[23][40][45][46][47][49]-[59]$} & $\begin{array}{l}\text { Potential double } \\
\text { count }\end{array}$ \\
Cochrane & {$[22][24][38][40][41][43][46][47][60][61][62]$} & \\
Antanopoulos et al. & {$[24][38][39][41][43][46][47][57][63]-[87]$} & \\
\hline
\end{tabular}


half the number of patients recruited to the BASIL trial [90] which showed no difference for PTA compared to bypass surgery for critical ischemia.

\section{Treatment of Femoral Artery Disease in the Presence of Severe Ischemia}

Trials so far listed have demonstrated little benefit in reducing mortality or limb loss because the bulk of the patients entering these trials suffered from IC. The reason for this is that it is easier to recruit patients with IC for a RCT.

"The Bypass versus angioplasty in severe ischemia of the leg (BASIL): multicentre, randomised controlled trial" [90] directly addressed the issue of treatment of CLI caused by femoral artery disease. The original trial randomised 452 patients to either bypass surgery first $(n=228)$ or PTA first $(n=224)$. At the end of follow up in the initial report in 2005, there was no difference in amputation free survival or overall survival between the two groups but cost and length of hospital stay were significantly greater for surgery first group and $37 \%$ of patients were dead ( $8 \%$ after amputation, 29\% without amputation). In 2010 the trial investigators published further follow up data [91] suggesting that for patients who survived more than 2 years after randomization, surgery first was associated with better overall survival. They claimed better amputation free survival, this did not reach statistical significance. During a subsequent mean follow up of 3.1 years $56 \%$ of all patients were dead (59\% in PTA group and 53\% in surgery group). This suggested that the possibility of selecting which patients would survive 2 years could have been predicted by the toss of a coin and their analysis suffered from retrospectivity. Trial investigators indulged in further retrospective analysis [92] and used this to justify further RCT [93] comparing 3 different endovascular treatments for femoral artery disease causing CLI. The results are yet to be published.

\section{Trials Driven by Technology}

There are a number of trials driven by advances in technology and these are most often industry supported. Table 3 lists trials of nitinol stents. Some are RCT's and some are cohort studies. The overwhelming number of participants in these trials suffered from IC. Examination of these trials suggests little benefit for routine stenting with nitinol stents.

Table 4 lists trials of covered stent technology. There are two trials, one of which was closed due to device failure, then restarted. The other showed no benefit for this type of technology compared to PTA.

Table 5 lists trials of Drug-eluting Balloons (DEB) and Drug-eluting Stents (DES). These devices are coated with Sirolimus [97] or Pacxlitaxel which are drugs that prevent the ingrowth of smooth muscle cells and therefore the development of stricture formation. These drugs are released from the balloon or stent over a variable period of time. The trials are mostly conducted on patients with IC, they frequently have questionable endpoints (freedom from binary 
Table 3. Trial of nitinol stents.

\begin{tabular}{|c|c|c|c|c|c|}
\hline $\begin{array}{l}\text { Author } \\
\text { (Year) }\end{array}$ & Trial & ?vs? & $\begin{array}{l}\text { \# of } \\
\text { Pts }\end{array}$ & $\begin{array}{l}\text { Clinical } \\
\text { Indication }\end{array}$ & Result \\
\hline $\begin{array}{l}\text { Krakenberg } \\
(2007)[47]\end{array}$ & $\begin{array}{l}\text { FAST } \\
\text { (RCT) }\end{array}$ & NS vs PTA & 244 & $\begin{array}{l}\text { 3/119 CLI NS } \\
\text { 4/114 CLI PTA } \\
226 \text { claudicants }\end{array}$ & $\begin{array}{l}\text { NS vs PTA } \\
\text { no difference }\end{array}$ \\
\hline $\begin{array}{c}\text { Zella (2008) } \\
\quad[94]\end{array}$ & FACT & $\begin{array}{l}\text { Long lesions, } \\
\text { non-randomised, } \\
\text { Single arm }\end{array}$ & 110 & Claudicants & $\begin{array}{l}\text { Only } 60 \\
\text { patients at } \\
\text { follow up }\end{array}$ \\
\hline $\begin{array}{l}\text { Laird (2012) } \\
{[65]}\end{array}$ & $\begin{array}{l}\text { RESILIENT } \\
\quad(\mathrm{RCT})\end{array}$ & NS vs PTA & 206 & $\begin{array}{l}\text { All claudicants } \\
\text { moderate length } \\
\text { lesions }\end{array}$ & $\begin{array}{c}\text { Claimed } \\
\text { superiority } \\
\text { for NS after } 3 \\
\text { yrs but no } \\
\text { duplex scan } \\
\text { after } 12 / 12 \text {. } \\
\text { Claimed } \\
\text { clinical } \\
\text { improvement }\end{array}$ \\
\hline $\begin{array}{l}\text { Chalmers } \\
(2012)[62]\end{array}$ & SUPER & $\begin{array}{l}\text { Smart NS vs } \\
\text { PTA }\end{array}$ & 150 & $\begin{array}{l}\text { Protocol amended } \\
\text { during study }\end{array}$ & No benefit \\
\hline $\begin{array}{c}\text { Bosiers } \\
(2013)[95]\end{array}$ & 4EVER & $\begin{array}{c}\text { Non-randomised } \\
4 \text { Fg NS }\end{array}$ & 120 & All claudicants & $\begin{array}{c}\text { Claimed } \\
\text { equivalence } \\
\text { to } 6 \mathrm{Fg} \text { system }\end{array}$ \\
\hline $\begin{array}{l}\text { Matsummura } \\
\text { (2013) [96] }\end{array}$ & Durability 2 & $\begin{array}{l}\text { Single Arm, long } \\
\text { stent }\end{array}$ & 287 & Claudicants $=273$ & $\begin{array}{l}\text { Efficacy trial } \\
\text { of long stents }\end{array}$ \\
\hline $\begin{array}{c}\text { Laird (2014) } \\
{[64]}\end{array}$ & CompleteSE & Single Arm & 196 & $\begin{array}{c}\text { Claudicants } \\
193 / 196 \\
\text { CLI 3/196 }\end{array}$ & $\begin{array}{l}\text { Claimed } \\
\text { 12-month } \\
\text { benefit }\end{array}$ \\
\hline
\end{tabular}

Table 4. Trials of covered stent technology.

\begin{tabular}{|c|c|c|c|c|c|}
\hline $\begin{array}{c}\text { Author } \\
\text { (Year) }\end{array}$ & Trial & ? vs? & $\begin{array}{l}\text { \# of } \\
\text { Pts }\end{array}$ & $\begin{array}{c}\text { Clinical } \\
\text { Indication }\end{array}$ & Results \\
\hline $\begin{array}{c}\text { Saxon } \\
(2003) \\
{[45]}\end{array}$ & $\begin{array}{l}\text { Single centre } \\
\text { reporting } \\
\text { experience } \\
\text { from } \\
\text { multicentre } \\
\text { trial }\end{array}$ & $\begin{array}{c}\text { PTFE stent vs } \\
\text { PTA } \\
\text { (Viabahn) }\end{array}$ & 28 & Claudicants & $\begin{array}{c}\text { Clinical } \\
\text { improvement no } \\
\text { different. } \\
\text { Conclusion different } \\
\text { from reported } \\
\text { results. Trial closed } \\
1999 .\end{array}$ \\
\hline $\begin{array}{c}\text { Saxon } \\
(2008) \\
{[101]}\end{array}$ & $\begin{array}{l}\text { RCT as from } \\
\text { Saxon (2003) }\end{array}$ & $\begin{array}{l}\text { PTFE stent } \\
\text { plus PTA } \\
\text { vs PTA } \\
\text { (Viabahn) }\end{array}$ & 100 & Claudicants & $\begin{array}{l}\text { Same trial as above } \\
\text { restarted. Flawed } \\
\text { methodology. }\end{array}$ \\
\hline $\begin{array}{c}\text { Lammer } \\
(2013) \\
{[67]}\end{array}$ & $\begin{array}{l}\text { RCT long } \\
\text { lesions }\end{array}$ & $\begin{array}{l}\text { Viabahn } \\
\text { heprin } \\
\text { bonded vs } \\
\text { BMS }\end{array}$ & 141 & Claudicants & $\begin{array}{l}\text { No difference in } \\
\text { 12-month primary } \\
\text { patency or } \\
\text { incidence of TLR. }\end{array}$ \\
\hline $\begin{array}{c}\text { Reijnen } \\
(2017) \\
{[102]}\end{array}$ & $\begin{array}{c}\text { RCT } \\
\text { multicentre }\end{array}$ & $\begin{array}{c}\text { Heparin } \\
\text { bonded } \\
\text { endoluminal } \\
\text { stent vs FP } \\
\text { bypass }\end{array}$ & 129 & $\begin{array}{c}\text { CLI } 38 \% \\
\text { endoluminal and } \\
32 \% \text { surgical. } \\
\text { Both groups } 2 / 3 \\
\text { Rutherford class } \\
2 / 3\end{array}$ & $\begin{array}{l}\text { No difference in } \\
\text { outcomes between } 2 \\
\text { groups. Results } \\
\text { similar to BASil } \\
\text { trial, but including } \\
\text { claudicants. }\end{array}$ \\
\hline
\end{tabular}


Table 5. Drug eluting technology.

\begin{tabular}{|c|c|c|c|c|c|}
\hline Author (Year) & Trial & ? vs? & \# of Pts & Clinical Indication & Results \\
\hline $\begin{array}{c}\text { Dudda } \\
(2006)[55]\end{array}$ & $\begin{array}{c}\text { RCT } \\
\text { SIRROCO }\end{array}$ & Smart vs DES (Smart) & $\mathrm{n}=93$ & $\begin{array}{l}\text { Claudicants/long } \\
\text { lesions }\end{array}$ & No difference \\
\hline $\begin{array}{c}\text { Liistro } \\
(2013)[66]\end{array}$ & $\begin{array}{l}\text { DEBATE } \\
\text { SFA RCT }\end{array}$ & $\begin{array}{c}\text { DEB and BMS vs PTA } \\
\text { and BMS }\end{array}$ & $\mathrm{n}=104$ & $\begin{array}{c}\text { For restenosis } \\
\text { Claud }=20.8 \%(11) \\
\text { vs } 31.4 \%(16) \\
\text { CLI }=79.2 \%(42) \text { vs } \\
\quad 68.6 \%(35)\end{array}$ & $\begin{array}{l}\text { Freedom from binary } \\
\text { restenosis better for DEB. } \\
\text { Not significant for TLR } \\
\text { or amp. }\end{array}$ \\
\hline $\begin{array}{l}\text { Rosenfield } \\
(2015)[69]\end{array}$ & $\begin{array}{c}\text { RCT } \\
\text { LEVANT2 }\end{array}$ & DEB vs PTA & $\begin{array}{c}\quad \mathrm{n}=476 \\
\text { Randomized 2:1 }\end{array}$ & Claudicants & $\begin{array}{l}12 / 12 \text { primary patency } \\
65.5 \% \text { vs } 52.6 \% \mathrm{p}=0.02 \\
\text { no significant difference } \\
\text { for function, death/amp, } \\
\text { thrombosis or } \\
\text { re-intervention }\end{array}$ \\
\hline Tepe (2015) [86] & $\begin{array}{l}\text { IN. PACT } \\
\text { SFA }\end{array}$ & DEB vs PTA RCT & $\begin{array}{l}\mathrm{DEB}=220 \\
\mathrm{PTA}=111\end{array}$ & $\begin{array}{l}\text { DEB }=209 / 220 \\
\text { Rutherford 2, } 3 \\
\text { PTA }=104 / 111 \\
\text { Rutherford 2, } 3\end{array}$ & $\begin{array}{l}\text { Freedom from Binary } \\
\text { restenosis, TLR. DEB } \\
\text { superior }\end{array}$ \\
\hline $\begin{array}{c}\text { Dake } \\
(2016)[68]\end{array}$ & $\begin{array}{c}\text { RCT } \\
\text { Zilver PTX }\end{array}$ & $\begin{array}{c}\text { PTA + BMS vs DES, } \\
\text { secondary bailout DES } \\
\text { vs BMS }\end{array}$ & $\begin{array}{l}\mathrm{DES}=236 \\
\mathrm{PTA}=238\end{array}$ & Claudicants & $\begin{array}{l}\text { At } 5 \text { years DES better } \\
\text { than PTA. Complicated } \\
\text { randomization. Only } \\
60 \% \text { of patients } \\
\text { available for } \mathrm{f} / \mathrm{u}\end{array}$ \\
\hline $\begin{array}{c}\text { Kinstner } \\
(2016)[103]\end{array}$ & $\begin{array}{c}\text { RCT } \\
\text { PACUBA }\end{array}$ & DEB vs PTA & $\mathrm{n}=74$ & $\begin{array}{l}\text { Symptomatic in-stent } \\
\text { restenosis }\end{array}$ & $\begin{array}{l}\text { ABSPI no different } \\
\text { at } 12 / 12 \text {, primary patency } \\
\text { better for DEB, TLR or } \\
\text { clinical improvement no } \\
\text { different }\end{array}$ \\
\hline $\begin{array}{c}\text { Muller-Hulsbeck et al. } \\
\text { (2016) [104] \& (2017) } \\
{[105]}\end{array}$ & MAJESTIC & $\begin{array}{l}\text { Cohort study } \\
\text { Single arm, multicentre } \\
\text { clinical trial }\end{array}$ & $\begin{array}{l}\text { Eluvia stent } \\
\qquad \mathrm{n}=57\end{array}$ & $\begin{array}{l}\text { Rutherford class } \\
\qquad 2,3 \& 4\end{array}$ & $\begin{array}{l}\text { Primary patency at } 24 \\
\text { months } 83.5 \% .36 \\
\text { months TLR } 85.3 \% .\end{array}$ \\
\hline $\begin{array}{c}\text { Jongsma } \\
(2017)[106]\end{array}$ & $\begin{array}{c}\text { RCT } \\
\text { FOREST }\end{array}$ & $\begin{array}{l}\text { DEB and provisional } \\
\text { stent vs DES }\end{array}$ & $\mathrm{n}=254$ & & No results until 2019 \\
\hline Bausback (2017) [107] & $\begin{array}{l}\text { Ranger } \\
\text { DEB }\end{array}$ & $\begin{array}{c}\text { RCT } \\
\text { DEB vs Standard PTA }\end{array}$ & $\begin{array}{l}\text { DEB } n=71 \\
\text { SPTA } n=34\end{array}$ & $\begin{array}{c}\text { All claudicants } \\
\text { Rutherford class } 2-4\end{array}$ & $\begin{array}{l}6 \text { months follow up only. } \\
\text { Superior freedom from } \\
\text { binary stenosis for DEB } \\
\text { and primary patency. } \\
\text { But only } 56 \% \text { and } 66 \% \text { of } \\
\text { pts followed up by } \\
\text { angiography. }\end{array}$ \\
\hline DeBoer (2017) [108] & $\begin{array}{c}\text { RCT } \\
\text { (RAPID) }\end{array}$ & $\begin{array}{l}\text { DEB and Stent vs } \\
\text { Standard balloon } \\
\text { and Stent }\end{array}$ & $\mathrm{N}=160$ & $\begin{array}{l}\text { Claudicants } \\
\text { intermediate to long } \\
\text { lesion Supera Stent }\end{array}$ & $\begin{array}{l}\text { No difference between } \\
\text { groups }\end{array}$ \\
\hline $\begin{array}{l}\text { Schroeder } \\
(2017)[109]\end{array}$ & RCT & $\begin{array}{l}\text { PTA and stent, } \\
\text { standard } \\
\text { balloon vs DEB }\end{array}$ & $\begin{array}{c}\mathrm{DEB}=222 \\
\text { St Balloon }=72\end{array}$ & Claudicants & $\begin{array}{l}\text { Superiority for DEB over } \\
\text { Standard PTA }\end{array}$ \\
\hline Gray (2018) [110] & IMPERIAL & $\begin{array}{c}\text { RCT } \\
\text { Eluvia vs Zilver }\end{array}$ & $\begin{array}{c}\text { Eluvia } \mathrm{n}=309 \\
\text { Zilver PTX } \\
\mathrm{n}=156\end{array}$ & $\begin{array}{l}\text { Non-inferiority trial. } \\
\text { Rutherford class } \\
2,3 \& 4 \text {. } \\
12 \text { months follow up }\end{array}$ & $\begin{array}{l}\text { Claimed Eluvia } \\
\text { equivalent to Zilver PTX. } \\
\text { Primary patency TLR } \\
\text { and adverse events. }\end{array}$ \\
\hline
\end{tabular}


restenosis or Target lesion revascularization, change of Rutherford class) or have complicated and questionable randomisation processes. A recent meta-analysis [98] came to the conclusion that there was little benefit from DEB's and there is only one trial showing benefit for DES. This trial had a questionable randomisation process, $40 \%$ of the patients were lost to follow up and the trial was industry driven. There is no substantial evidence that new technologies have a role to play in the treatment of IC caused by atherosclerotic disease of the femoral artery.

\section{Conclusions}

Atherosclerotic disease of the femoral artery is a marker for advanced systemic cardiovascular disease. It is most prevalent in the population of individuals greater than 65 years of age. Most frequently it is an asymptomatic condition. Its detection and management should remain in the realm of primary care physicians.

Many RCT which address treatment of this condition are flawed because of commercial objectives to demonstrate equivalence to an already approved procedure, because of the use of clinically fallacious end points, because the use of follow up periods that do not extend beyond expired advantage and because the sample population is too small or unrepresentative.

While meta-analyses of these RCT's are designed to increase sample size, what is in fact achieved is a compounding and magnification of these flaws.

Most trials that address treatment of this condition are conducted on patients who have claudication and do not have an indication for intervention other than the conduct of the trial. Industry funding of these trials makes it highly unlikely that the results will be challenged after a positive result has been obtained. There is profound profit motive to obtain and publish only trials with positive results. Investigators often have a similar conflict of interest. Authors rarely declare the intellectual ownership of a positive result from a previous trial. Meta-analyses of these trials are often flawed by compounding these biases [99] [100].

\section{Conflicts of Interest}

The author declares no conflicts of interest regarding the publication of this paper.

\section{References}

[1] Diehm, C., Schuster, A., Allenberg, J.R., Darius, H., Haberl, R., Lange, S., Pittrow, D., von Stritzky, B., Tephohl, G. and Trampisch, H.-J. (2004) High Prevalence of Peripheral Arterial Disease and Co-Morbidity in 6880 Primary Care Patients: Cross-Sectional Study. Atherosclerosis, 172, 95-105.

[2] Meijer, W.T., Hoes, A.W., Rutgers, D., Bots, M.L., Hofman, A. and Grobbee, D.E. (1998) Peripheral Arterial Disease in the Elderly: The Rotterdam Study. Arteriosclerosis, Thrombosis, and Vascular Biology, 18, 185-192.

[3] Hobbs, S.D. and Bradbury, A.W. (2006) The Exercise versus Angioplasty in Claudication Trial (EXACT): Reasons for Recruitment Failure and the Implications for 
Research into Treatment of Intermittent Claudication. Journal of Vascular Surgery,44, 432-433

[4] Ratliff, D.A., Puttick, M., Libertiny, G., Hicks, R.C.J., Earby, L.E. and Richards, T. (2007) Supervised Exercise Training for Intermittent Claudication: Lasting Benefit at Three Years. European Journal of Vascular and Endovascular Surgery, 34, 322-326. https://doi.org/10.1016/j.ejvs.2007.04.014

[5] Lane, R., Harwood, A., Watson, L. and Leng, G.C. (2017) Exercise for Intermittent Claudication. Cochrane Database of Systematic Reviews, No. 12, Article No. CD000990. https://doi.org/10.1002/14651858.CD000990.pub4

[6] Mazari, F.A., Carradice, D., Norhisham, M.A., Rahman, A., Khan, J.A., Mockford, K., Mehta, T., McCollum, P.T. and Chetter, I.C. (2010) An Analysis of Relationship between Quality of Life Indices and Clinical Improvement Following Intervention in Patients with Intermittent Claudication Due to Femoropopliteal Disease. Journal of Vascular Surgery, 52, 77-84

[7] Aherne, T., McHugh, S., Kheirelseid, E.A., Lee, M.J., McCaffrey, N., Moneley, D., Austin, L.L. and Naughton, P. (2015) Comparing Supervised Exercise Therapy to invasive Measures in the Management of Symptomatic Peripheral Arterial Disease. Surgical Research and Practice, 2015, Article ID: 960402. https://doi.org/10.1155/2015/960402

[8] Creasy, T.S., McMillan, P.J., Fletcher, E.W.L., Collin, J. and Morris, P.J. (1990) Is Percutaneous Transluminal Angioplasty Better than Exercise for Claudication? -Preliminary Results from a Prospective Randomised Trial. European Journal of Vascular Surgery, 4, 135-140. https://doi.org/10.1016/S0950-821X(05)80427-X

[9] Perkins, J.M.T., Collin, J., Creasy, T.S., Fletcher, E.W.L. and Morris, P.J. (1996) Exercise Training versus Angioplasty for Stable Claudication. Long and Medium-Term Results of a Prospective, Randomised Trial. European Journal of Vascular and Endovascular Surgery, 11, 409-413. https://doi.org/10.1016/S1078-5884(96)80171-7

[10] Whyman, M.R., Fowkes, F.G.R., Kerraccher, E.M.G., Gillespie, I.N., Lee, A.J., Housley, E. and Ruckley, C.V. (1996) Randomised Controlled Trial of Percutaneous Transluminal Angioplasty for Intermittent Claudication. European Journal of Vascular and Endovascular Surgery, 12, 167-172. https://doi.org/10.1016/S1078-5884(96)80102-X

[11] Whyman, M.R., Fowkes, F.G.R., Keracher, E.M.G., Gillespie, I.N., Lee, A.J., Housley, E. and Ruckley, C.V. (1997) Is Intermittent Claudication Improved by Percutaneous Transluminal Angioplasty? A Randomised Controlled Trial. Journal of Vascular Surgery, 26, 551-557.

[12] Nylaende, M., Abdelnoor, M., Stranden, E., Morken, B., Sandaek, G., Risum, O., Jorgensen, J.J., Kindahl, A.K., Arnesen, H., Seljeflot, L. and Kroese, A.J. (2007) The Oslo Balloon Angioplasty versus Conservative Treatment Study(OBACT)-The 2-Year Results of a Single Centre, Prospective, Randomised Study in Patients with Intermittent Claudication. European Journal of Vascular and Endovascular Surgery, 33, 3-12.

[13] Greenhalgh, R.M., Belch, J.J., Brown, L.C., Gaines, P.A., Gao, L. and Reise, J.A. (2008) The Adjuvant Benefit of Angioplasty in Patients with Mild to Moderate Intermittent Claudication (MIMIC). European Journal of Vascular and Endovascular Surgery, 36, 680-688.

[14] Spronk, S., Boscch, J.L., den Hoed, P.T., Veen, H.F., Pattynama, P.M. and Hunink, M.G. (2008) Cost Effectiveness of Endovascular Revascularisation Compared to Supervised Hospital-Based Exercise Training in Patients with Intermittent Claudi- 
cation: A Randomized Controlled Trial. Journal of Vascular Surgery, 48, 1472-1480. https://doi.org/10.1016/j.jvs.2008.06.016

[15] Mazari, F.A., Khan, J.A., Carradice, D., Samuel, N., Abdul Rahman, M.N. and Gulati, S. (2012) Randomized Clinical Trial of Percutaneous Transluminal Angioplasty, Supervised Exercise Training and Combined Treatment for Intermittent Claudication Due to Femoropopliteal Arterial Disease. British Journal of Surgery, 99, 38-48. https://doi.org/10.1002/bjs.7710

[16] Muradin, G.S., Bosch, J.L., Stijen, T. and Hunink, M.G. (2002) Balloon Dilation and Stent Implantation for Treatment of Femoropopliteal Artery Disease: Meta-Analysis. Radiology, 224, 137-145

[17] YaJun, E., Neng, S.H., Wang, Y. and Fan, H. (2008) Percutaneous Transluminal Angioplasty (PTA) Alone versus PTA with Balloon-Expandable Stent Placement for Short Segment Femoropopliteal Artery Disease: A Meta-Analysis of Randomized Trials. Journal of Vascular and Interventional Radiology, 19, 499-503. https://doi.org/10.1016/j.jvir.2007.12.446

[18] Mwipatayi, B.P., Hockings, A., Hoffman, M., Garbowski, M. and Sieunarine, K. (2008) Balloon Angioplasty Compared with Stenting for Treatment of Femoro-Popliteal Occlusive Disease: A Meta-Analysis. Journal of Vascular Surgery, 47, 461-469

[19] Kasapis, C., Henke, P.K., Chetcuti, S.J., Koenig, G.C., Rectenwald, J.E., Krishnamrthy, V.N., Grossman, P.M. and Gurm, H.S. (2009) Routine Stent Implantation vs. Percutaneous Transluminal Angioplasty in Femoro-Popliteal Artery Disease: A Meta-Analysis of Randomised Controlled Trials. European Heart Journal, 30, 44-55. https://doi.org/10.1093/eurheartj/ehn514

[20] Perrio, S., Holt, P.J.E., Patterson, B.O., Hinchliffe, R.J., Loftus, I.M. and Thompson, M.M. (2010) Role of Superficial Arterial Stents in the Management of Arterial Occlusive Disease: Review of the Current Evidence. Vascular, 18, 82-92.

[21] Chowdhury, M.M., McLain, A.D. and Twine, C.P. (2014) Angioplasty versus Bare Metal Stenting for Superficial Femoral Artery Lesions. Cochrane Data Base of Systematic Reviews, No. 6, Article No. CD006767.

https://doi.org/10.1002/14651858.CD006767.pub3

[22] Vroegindeweij, D., Vos, L.D., Tielbeek, A.V., Buth, J. and vd Bosch, H.C. (1997) Balloon Angioplasty Combined with Primary Stenting versus Balloon Angioplasty Alone in Femoropopliteal Obstructions: A Comparative Randomized Study. Cardio Vascular and Interventional Radiology, 20, 420-425. https://doi.org/10.1007/s002709900186

[23] Cheng, S.W., Ting, A.C. and Wong, J. (2001) Endovascular Stenting of Superficial Femoral Artery Stenosis and Occlusions: Results and Risk Factor Analysis. Cardiovascular Surgery, 9, 133-140.

[24] Becquemin, J.-P., Favre, J.-P., Marzelle, J., Nemoz, C., Corsin, C. and Leizorovicz, A. (2003) Systematic versus Selective Stent Placement after Superficial Femoral Artery Balloon Angioplasty: A Multicentre Prospective Randomized Study. Journal of Vascular Surgery, 37, 487-494.

[25] Tielbeek, A.V., Vroegindeweij, D., Buth, J., et al. (1996) Comparison of Balloon Angioplasty and Simpson Atherectomy for Lesions in the Femoropopliteal Artery: Angiographic and Clinical Results of a Prospective Randomized Trial. Journal of Vascular and Interventional Radiology, 7, 837-844. https://doi.org/10.1016/S1051-0443(96)70857-6

[26] Henry, M., Amor, M., Ethevenot, G., et al. (1995) Palmaz Stent Placement in Iliac 
and Femoro-Popliteal Arteries: Primary and Secondary Patency in 310 Patients with 2-3 Years Follow Up. Radiology, 197, 167-174.

https://doi.org/10.1148/radiology.197.1.7568818

[27] Strecker, P., Boos, I.B. and Gottman, D. (1997) Femoropopliteal Sent Placement: Evaluation of Long Term Success. Radiology, 205, 375-383.

https://doi.org/10.1148/radiology.205.2.9356617

[28] Jeans, W.D., Cole, S.D., Horrocks, M., et al. (1994) Angioplasty Gives Good Results in Critical Lower Limb Ischemia. A 5-Year Follow Up in Patients with Known Ankle Pressure and Diabetic Status Having Femoropopliteal Dilations. The British Journal of Radiology, 67, 123-128. https://doi.org/10.1259/0007-1285-67-794-123

[29] Murray, J.G., Apthorp, L.A. and Wilkins, R.A. (1995) Long Segment $(>10 \mathrm{~cm})$ Femoropopliteal Angioplasty: Improved Technical Success and Long-Term Patency. Radiology, 195, 158-162. https://doi.org/10.1148/radiology.195.1.7892459

[30] Stanley, B., Teague, B., Raptis, S., et al. (1996) Efficacy of Balloon Angioplasty of the Superficial Femoral Artery and Popliteal Artery in the Relief of Leg Ischemia. Journal of Vascular Surgery, 23, 679-685.

[31] Martin, D.R., Katz, S.G., Kohl, R.D., et al. (1999) Percutaneous Transluminal Angioplasty of the Infra Inguinal Vessels. Annals of Vascular Surgery, 13, 184-187.

[32] Golledge, J., Ferguson, K., Ellis, M., Sabharwal, T., Davies, A., Greenhalgh, R. and Powell, J. (1999) Outcome of Femororpopliteal Angioplasty. Annals of Surgery, 229, 146-153. https://doi.org/10.1097/00000658-199901000-00019

[33] O'Donohoe, M.K., Sultan, S., Colgan, M.P., et al. (1999) Outcome of the First 100 Femoropopliteal Angioplasties Performed in the Operating Theatre. European Journal of Vascular and Endovascular Surgery, 17, 66-71.

[34] Karch, L.A., Mattos, M.A., Henretta, J.P., et al. (2000) Clinical Failure after Percutaneous Transluminal Angioplasty of the Superficial Femoral and Popliteal Arteries. Journal of Vascular Surgery, 31, 880-887.

[35] Martin, E.C., Katzen, B.T., Benenati, J.F., et al. (1995) Multicenter Trial of the Wall Stent in the Iliac and Femoral Arteries. Journal of Vascular and Interventional Radiology, 6, 843-849.

[36] White, G., Liew, S.C., Waugh, R.C., et al. (1995) Early Outcome and Intermediate Follow Up of Vascular Stents in the Femoral and Popliteal Arteries without Long Term Anticoagulation. Journal of Vascular Surgery, 21, 270-281. https://doi.org/10.1016/S0741-5214(95)70268-7

[37] Bergeron, P., Pinot, J.J., Poyen, V., et al. (1995) Long-Term Results with the Palmaz Stent in the Superficial Femoral Artery. Journal of Endovascular Therapy, 2, 161-167. https://doi.org/10.1583/1074-6218(1995)002<0161:ALTRWT>2.0.CO;2

[38] Cejna, M., Thurnher, S., Illiasch, H., Horvath, W., Waldenberger, P., Hornik, K. and Lammer, J. (2001) PTA versus Palmaz Stent Placement in Femoro-Popliteal Artery Obstructions: A Multicentre Prospective Randomized Study. Journal of Vascular and Interventional Radiology, 12, 23-31. https://doi.org/10.1016/S1051-0443(07)61397-9

[39] Cejna, M., Schoder, M. and Lammer, J. (1999) PTA vs Stent in Femoropopliteal Obstruction. Radiologe, 39, 144-150.

[40] Zdanowski, Z., Albrechtsson, U., Lundin, A., Jonung, T., Ribbe, E., Thorne, J. and Norgren, L. (1999) Percutaneous Transluminal Angioplasty with or without Stenting for Femoropopliteal Occlusions? A Randomized Controlled Study. International Angiology, 18, 251-255.

[41] Grimm, J., Muller-Hulsbeck, S., Janke, T., et al. (2001) Randomized Study to Com- 
pare PTA Alone versus PTA with Palmaz Stent Placement for Femoropopliteal Lesions. Journal of Vascular and Interventional Radiology, 12, 935-942.

[42] Pozzi Mucelli, P., Fisicaro, M., Calderan, L., Malacrea, M., Mazzone, C., Cattin, L., Scardi, S. and Pozzi Mucelli, R. (2003) Percutaneous Revascularization of Femoropopliteal Artery Disease: PTA and PTA Plus Stent. Results after Six Years' Follow-Up. La Radiologia Medica, 105, 339-349.

[43] Grenacher, L., Saam, T., Geier, A., Muller-Hulsbeck, S., Cejna, M., Kauffman, G.W. and Richter, G.M. (2004) PTA versus Palmaz Stent Placement in Femororpopliteal Artery Stenosis: Results of a Multicentre Prospective Randomized Study (REFSA). Rofo, 176, 1302-1310.

[44] Rand, T., Basile, A., Cejna, M., et al. (2006) PTA versus Carbofilm Coated Stents in Infrapopliteal Arteries: Pilot Study. CardioVascular and Interventional Radiology, 29, 29-38.

[45] Saxon, R.R., Coffman, J.M., Gooding, J.M., Natuzzi, E. and Ponec, D.J. (2003) Long-Term Results of ePTFE Stent-Graft versus Angioplasty in the Femoropopliteal Artery: Single Center Experience from a Prospective, Randomized Trial. Journal of Vascular and Interventional Radiology, 14, 303-311.

[46] Schillinger, M., Sabeti, S., Loewe, C., Dick, P., Amighi, J., Mlekusch, W., Schlager, O., Cejna, M., Lammer, J. and Minar, E. (2006) Balloonn Angioplasty versus Implantation of Nitinol Stents in the Superficial Femoral Artery. The New England Journal of Medicine, 354, 1879-1888. https://doi.org/10.1056/NEJMoa051303

[47] Krankenberg, H., Schluter, M., Steinkamp, H.J., Burgelin, K., Scheinert, D., Schulte, K.-D., Minar, E., Peeters, P., Bosiers, M., Tepe, G., Reimers, B., Mahler, F., Tubler, T. and Zeller, T. (2007) Nitinol Stent Implantation versus Percutaneous Transluminal Angioplasty in Superficial Femoral Artery Lesions Up to $10 \mathrm{~cm}$ in Length. The Femoral Artery Stenting Trial (FAST). Circulation, 116, 285-292. https://doi.org/10.1161/CIRCULATIONAHA.107.689141

[48] US Food and Drug Administration (2001) Center for Devices and Radiological Health. Intracoil Self Expanding Peripheral Stent-P00033. https://www.accessdata.fda.gov/cdrh_docs/pdf/P000033b.pdf.

[49] Gray, B.H., Sullivan, T.M., Childs, M.B., Young, J.R. and Olin, J.W. (1997) High Incidence of Restenosis/Reocclusion of Stents in the Percutaneous Treatment of Long-Segment Superficial Femoral Artery Disease after Suboptimal Angioplasty. Journal of Vascular Surgery, 25, 74-83.

[50] Conroy, R.M., Gordon, I.L., Tobis, J.M., Hiro, T., Kasaoka, S., Stemmer, E.A. and Wilson, S.E. (2000) Angioplasty and Stent Placement in chronic Occlusion of the Superficial Femoral Artery: Technique and Results. Journal of Vascular and Interventional Radiology, 11, 1009-1020.

[51] Vogel, T.R., Shindelman, L.E., Nackman, G.B. and Graham, A.M. (2003) Efficacious Use of Nitinol Stents in the Femoral and Popliteal Artery. Journal of Vascular Surgery, 38, 1178-1184.

[52] Sabeti, S., Schillinger, M., Amighi, J., Sherif, C., Mlekusch, W., Ahmadi, R. and Minar, E. (2004) Primary Patency of Femoro-Popliteal Arteries Treated with Nitinol versus Stainless Steel Self-Expanding Stents: Propensity Score Adjusted Analysis. Radiology, 232, 516-521.

[53] Abahji, T.N., Tato, F., Rieger, J., Offner, A., Will, S., Hoelscher, G., Weiss, N. and Hoffmann, U. (2006) Stenting of the Superficial Femoral Artery after Suboptimal Balloon Angioplasty: One Year Results. International Angiology, 25, 184-189.

[54] Lenti, M., Cieri, E., De Rango, P., Pozzilli, P., Coscarella, C., Bertoglio, C., Troiani, 
R. and Cao, P. (2007) Endovascular Treatment of Long Lesions of the Superficial Femoral Artery: Results from a Multicentre Registry of a Spiral, Covered Polytetrafluroethylene Stent. Journal of Vascular Surgery, 45, 32-39.

[55] Duda, S.H., Bosiers, M., Lammer, J., Scheinert, D., Zeller, T., Oliva, V., Tielbeek, A., Anderson, J., Wiesinger, B., Tepe, G., Lansky, A, Jaff, M.R., Mudde, C., Tielemans, H. and Beregi, J.-P. (2006) Drug-Eluting and Bare Nitinol Stents for the Treatment of Atherosclerotic Lesions in the Superficial Femoral Artery: Long-Term Results from the SIROCCO Trial. Journal of Endovascular Therapy, 13, 701-710. https://doi.org/10.1583/05-1704.1

[56] Inhat, D.M., Duong, S.T. and Taylor, Z.T. (2008) Contemporary Outcomes after Superficial Femoral Artery Angioplasty and Stenting: the Influence of TASC Classification and Run off Score. Journal of Vascular Surgery, 47, 967-974.

[57] Surowiec, S.M., Davies, M.G., Eberly, S.W., Rhodes, J.M., Illig, K.A., Shortell, C.K., Lee, D.E., Waldman, D.L. and Green, R.M. (2005) Percutaneous Angioplasty and Stenting of the Superficial Femoral Artery. Journal of Vascular Surgery, 41, 269-278.

[58] Schmeider, G., Richardson, A., Scott, E., Stokes, G.K., Meier, G.H. and Panneton, J.M. (2008) Selective Stenting in Subintimal Angioplasty: Analysis of Primary Stent Outcomes. Journal of Vascular Surgery, 48, 1175-1181.

[59] Ferriera, M., Lanziotti, L., Monteiro, M., Abuhadba, G., Capotorto, L.F., Nolte, L. and Fearnot, N. (2007) Superficial Femoral Artery Recanalization with Self-Expanding Nitinol Stents: Long Term Follow Up Results. European Journal of Vascular and Endovascular Surgery, 34, 702-708.

[60] Dick, P., Wallner, H., Sabeti, S., et al. (2009) Balloon Angioplasty versus Stenting with Nitinol Stents in Intermediate Length Superficial Femoral Artery Lesions. Catheterization and Cardiovascular Interventions, 74, 1090-1095.

https://doi.org/10.1002/ccd.22128

[61] Bosiers, M., Peters, P., Krakenberg, H., et al. (2006) The Femoral Artery Stenting Trial (FAST): 12 Month Outcomes. Abstract from 2006 SVS Annual Meeting.

[62] Chalmers, N., Walker, P.T., Belli, A.-M., Thorpe, A.P., Sidhu, P.S., Robinson, G., Van Ransbeeck, M. and Fearn, S.A. (2013) Randomized Trial of the SMART Stent versus Balloon Angioplasty in Long Superficial Femoral Artery Lesions: The SUPER Study. Cardio Vascular and Interventional Radiology, 36, 353-361. https://doi.org/10.1007/s00270-012-0492-Z

[63] Becquemin, J.-P., Cavillon, A. and Haiduc, F. (1994) Surgical Transluminal Angioplasty: Multivariate Analysis Outcome. Journal of Vascular Surgery, 19, 495-502. https://doi.org/10.1016/S0741-5214(94)70077-X

[64] Laird, J.R., Jain, A., Zeller, T., Feldman, R., Scheinert, D., Popma, J.J., Armstrong, E.J., Jaff, M.R., et al. (2014) Nitinol Stent Implantation in the Superficial Femoral Artery and Proximal Popliteal Artery: Twelve-Month Results from the Complete SE Multicenter Trial. Journal of Endovascular Therapy, 21, 202-212. https://doi.org/10.1583/13-4548R.1

[65] Laird, J.R., Katzen, B.T., Scheinert, D., Lammer, J., Carpenter, J., Buchbinder, M., Dave, R., Ansel, G., Lansky, A., Cristea, E., Collins, T.J., Goldstein, J., Cao, A.Y. and Jaff, M.R. (2012) Nitinol Stent Implantation vs. Balloon Angioplasty for Lesions in the Superficial Femoral and Proximal Popliteal Arteries with Claudication: Three-Year Follow-Up from the RESILIENT Randomized Trial. Journal of Endovascular Therapy, 19, 1-19.

[66] Liistro, F., Grotti, S., Porto, I., Angioli, P., Ricci, L., Ducci, K., Falsini, G., Ventoruzzo, G., Turini, F., Bellandi, G. and Bolognese, L. (2013) Drug-Eluting Balloon in Peripheral Intervention for the Superficial Femoral Artery. The DEBATE-SFA 
Randomized Trial (Drug Eluting Balloon in Peripheral Intervention for the Superficial Femoral Artery). JACC: Cardiovascular Interventions, 6, 1295-302.

[67] Lammer, J., Zeller, T., Hausegger, K.A., Schaefer, P.J., Gschwendtner, M., Mueller-Huelsbeck, S., Rand, T., Funovics, M., Wolf, F., Rastan, A., Gschwandtner, M., Puchner, S., Ristl, R. and Schoder, M. (2013) Heparin-Bonded Covered Stents Versus Bare-Metal Stents for Complex Femoropopliteal Artery Lesions. The Randomized VIA STAR Trial (Viabahn Endoprosthesis With PROPATEN Bioactive Surface [VIA] versus Bare Nitinol Stent in the Treatment of Long Lesions in Superficial Femoral Artery Occlusive Disease). JACC: Journal of the American College of Cardiology, 62, 1320-1327.

[68] Dake, M.D., Ansel, G.M., Jaff, M.R., Ohki, T., Saxon, R.R., Smouse, B., Machan, L.S., Snyder, S.A., O’Leary, E.E., Ragheb, A.O., Zeller, T., et al. (2016) Durable Clinical Effectiveness with Paclitaxel-Eluting Stents in the Femoropopliteal Artery. Circulation, 133, 1472-1483.

[69] Rosenfield, K., et al. (2015) Trial of a Paclitaxel-Coated Balloon for Femoropopliteal Artery Disease The New England Journal of Medicine, 373, 145-153.

[70] Tepe, G., Laird, J., Schneider, P., et al. (2015) Drug-Coated Balloon versus Standard Percutaneous Transluminal Angioplasty for the Treatment of Superficial Femoral and Popliteal Peripheral Artery Disease, 12 Months Results from the IN. PACT SFA Randomized Trial. Circulation, 131, 495-502.

https://doi.org/10.1161/CIRCULATIONAHA.114.011004

[71] Banerjee, S., Das, T., Abu-Fadel, M., Dippel, E., Shammas, N., Tran, D., Zankar, A., Varghese, C., Kelly, K., Weideman, R., Little, B., Reilly, R., Addo, T. and Brilakis, E. (2012) Pilot Trial of Cryoplasty or Conventional Balloon Post-Dilation of Nitinol Stents for Revascularization of Peripheral Arterial Segments. Journal of the American College of Cardiology, 60, 1352-1359. https://doi.org/10.1016/j.jacc.2012.05.042

[72] Lepäntalo, M., Laurila, K., Roth, W., Rossi, P., Lavonen, J., Mäkinen, K., Manninen, H., Romsi, P., Perälä, J., Bergqvist, D., et al. (2009) PTFE Bypass or Thrupass for Superficial Femoral Artery Occlusion? A Randomised Controlled Trial. European Journal of Vascular and Endovascular Surgery, 37, 578-584. https://doi.org/10.1016/j.ejvs.2009.01.003

[73] van der Zaag, E., Legemate, D., Prins, M., Reekers, J. and Jacobs, M. (2004). Angioplasty or Bypass for Superficial Femoral Artery Disease? A Randomised Controlled Trial. European Journal of Vascular and Endovascular Surgery, 28, 132-137. https://doi.org/10.1016/j.ejvs.2004.04.003

[74] Brancaccio, G. et al. (2012) Comparison of Embolic Load in Femoropopliteal Interventions: Percutaneous Transluminal Angioplasty versus Stenting. Vascular and Endovascular Surgery, 46, 229-235. https://doi.org/10.1177/1538574411422276

[75] Diaz, M., Urtasun, F., Barberena, J., Aranzadi, C., Guillen-Grima, F. and Bilbao, J. (2011) Cryoplasty versus Conventional Angioplasty in Femoropopliteal Arterial Recanalization: 3-Year Analysis of Reintervention-Free Survival by Treatment Received. Cardio Vascular and Interventional Radiology, 34, 911-917. https://doi.org/10.1007/s00270-010-0032-7

[76] Diehm, N. et al. (2005) Endovascular Brachytherapy after Femoropopliteal Balloon Angioplasty Fails to Show Robust Clinical Benefit over Time. Journal of Endovascular Therapy, 12, 723-730. https://doi.org/10.1583/05-1583MR.1

[77] Fossaceca, R., Guzzardi, G., Di Terlizzi, M., Divenuto, I., Malatesta, E., Cerini, P., Cusaro, C. and Carriero, A. (2012) Comparison of Cryoplasty and Conventional Angioplasty for Treating Stenotic-Occlusive Lesions of the Femoropopliteal Arteries 
in Diabetic Patients: Immediate, Mid-Term and Long-Term Results. La Radiologia Medica, 117, 1176-1189. https://doi.org/10.1007/s11547-012-0793-7

[78] Geraghty, P., Mewissen, M., Jaff, M. and Ansel, G. (2013) Three-Year Results of the VIBRANT Trial of VIABAHN Endoprosthesis versus Bare Nitinol Stent Implantation for Complex Superficial Femoral Artery Occlusive Disease. Journal of Vascular Surgery, 58, 386-395.e4. https://doi.org/10.1016/j.jvs.2013.01.050

[79] Krueger, K., Zaehringer, M., Bendel, M., Stuetzer, H., Strohe, D., Nolte, M., Wittig, D., Mueller, R. and Lackner, K. (2004) De Novo Femoropopliteal Stenoses: Endovascular Gamma Irradiation Following Angioplasty-Angiographic and Clinical Follow-Up in a Prospective Randomized Controlled Trial. Radiology, 231, 546-554. https://doi.org/10.1148/radiol.2312030421

[80] Pokrajac, B., Pötter, R., Maca, T., Fellner, C., Mittlböck, M., Ahmadi, R., Seitz, W. and Minar, E. (2000) Intraarterial 192Ir High-Dose-Rate Brachytherapy for Prophylaxis of Restenosis after Femoropopliteal Percutaneous Transluminal Angioplasty: The Prospective Randomized Vienna-2-Trial Radiotherapy Parameters and Risk Factors Analysis. International Journal of Radiation Oncology Biology Physics, 48, 923-931. https://doi.org/10.1016/S0360-3016(00)00716-1

[81] Pokrajac, B., Pötter, R., Wolfram, R., Budinsky, A., Kirisits, C., Lileg, B., Mendel, H., Sabeti, S., Schmid, R. and Minar, E. (2005) Endovascular Brachytherapy Prevents Restenosis after Femoropopliteal Angioplasty: Results of the Vienna-3 Randomised Multicenter Study. Radiotherapy and Oncology, 74, 3-9.

https://doi.org/10.1016/j.radonc.2004.08.015

[82] Poncyljusz, W., Falkowski, A., Safranow, K., Rać, M. and Zawierucha, D. (2013) Cutting-Balloon Angioplasty Versus Balloon Angioplasty as Treatment for Short Atherosclerotic Lesions in the Superficial Femoral Artery: Randomized Controlled Trial. Cardio Vascular and Interventional Radiology, 36, 1500-1507. https://doi.org/10.1007/s00270-013-0603-5

[83] Rastan, A., Krankenberg, H., Baumgartner, I., Blessing, E., Müller-Hülsbeck, S., Pilger, E., Scheinert, D., Lammer, J., Gißler, M., Noory, E., Neumann, F. and Zeller, T. (2013) Stent Placement versus Balloon Angioplasty for the Treatment of Obstructive Lesions of the Popliteal Artery. Circulation, 127, 2535-2541. https://doi.org/10.1161/CIRCULATIONAHA.113.001849

[84] Scheinert, D., Duda, S., Zeller, T., Krankenberg, H., Ricke, J., Bosiers, M., Tepe, G., Naisbitt, S. and Rosenfield, K. (2014) The LEVANT I (Lutonix Paclitaxel-Coated Balloon for the Prevention of Femoropopliteal Restenosis) Trial for Femoropopliteal Revascularization. JACC: Cardiovascular Interventions, 7, 10-19.

[85] Spiliopoulos, S., Katsanos, K., Karnabatidis, D., Diamantopoulos, A., Kagadis, G., Christeas, N. and Siablis, D. (2010) Cryoplasty versus Conventional Balloon Angioplasty of the Femoropopliteal Artery in Diabetic Patients: Long-Term Results from a Prospective Randomized Single-Center Controlled Trial. CardioVascular and Interventional Radiology, 33, 929-938. https://doi.org/10.1007/s00270-010-9915-x

[86] Tepe, G., Schnorr, B., Albrecht, T., Brechtel, K., Claussen, C., Scheller, B., Speck, U. and Zeller, T. (2015) Angioplasty of Femoral-Popliteal Arteries with Drug-Coated Balloons. JACC: Cardiovascular Interventions, 8, 102-108. https://doi.org/10.1016/j.jcin.2014.07.023

[87] van Tongeren, R.B., van Sambeek, M.R., van Overhagen, H., Coen, V.L., Schmitz, P.I., Gescher, F.M., Wittens, C.H., Vernhout, R.M., van Urk, H., Levendag, P.C. and Bruijninckx, C.M. (2005) Endovascular Brachytherapy for the Prevention of Restenosis after Femoropopliteal Angioplasty. Results of the VARA Trial. The Journal of Cardiovascular Surgery, 46, 437-443. 
[88] Antonopoulos, C.N., Mylonas, S.N., Moulakakis, K.G., Sergentanis, T.N., Sfyroeras, G.S., Lazaris, A.M., Kakisis, J.D. and Vasdekis, S.N. (2017) A Network Meta-Analysis of Randomized Controlled Trials Comparing Treatment Modalities for De Novo Superficial Femoral Artery Occlusive Lesions. Journal of Vascular Surgery, 65, 234-245.

[89] Kedora, J., Hohmann, S., Garrett, W., Munschaur, C., Theune, B. and Gable, D. (2007) Randomized Comparison of Percutaneous Viabahn Stent Grafts vs Prosthetic Femoral-Popliteal Bypass in the Treatment of Superficial Femoral Arterial Occlusive Disease. Journal of Vascular Surgery, 45, 10-16. https://doi.org/10.1016/j.jvs.2006.08.074

[90] BASIL Trial Participants (2005) Bypass versus Angioplasty in Severe Ischaemia of the Leg (BASIL): Multicentre, Randomised Controlled Trial. The Lancet, 366, 1925-1934. https://doi.org/10.1016/S0140-6736(05)67704-5

[91] Bradbury, A.W., Adam, D.J., Bell, J., Forbes, J.F., Fowkes, G.R., Gillespie, I., Vaughan Ruckley, C. and Raab, G.M. (2010) Bypass versus Angioplasty in Severe Ischaemia of the Leg (BASIL) Trial: An Intention-to-Treat Analysis of Amputation-Free and Overall Survival in Patients Randomised to a Bypass Surgery First or a Balloon Angioplasty First Revascularization Strategy. Journal of Vascular Surgery, $51,5 \mathrm{~s}-17 \mathrm{~s}$.

[92] Popplewell, M.A., Davies, H.O.B., Narayanswami, J., Renton, M., Sharp, A., Bate, G., Patel, S., Deeks, J., Bradbury, A.W. (2017) A Comparison of Outcomes in Patients with Infrapopliteal Disease Randomised to Vein Bypass or Plain Balloon Angioplasty in the Bypass vs. Angioplasty in Severe Ischaemia of the Leg (BASIL) Trial. European Journal of Vascular and Endovascular Surgery, 54,195-201.

[93] Hunt, B.D., Popplewell, M.A., Davies, H., Meecham, L., Jarrett, H., Bate, G., Grant, M., Patel, S., Hewitt, C., Andronis, L., Deeks, J.J., Bradbury, A. and BASIL-3 Collaborative Group (2017) BAlloon versus Stenting in Severe Ischaemia of the Leg-3 (BASIL-3): Study Protocol for a Randomised Controlled Trial. Trials, 18, 224.

[94] Zeller, T., Tiefenbacher, C., Steinkamp, H.J., Langhoff, R., Wittenberg, G., Schluter, M., Buergelin, K., Rastan, A., Krumsdorf, U., Sixt, S., Schulte, C.-L., Tubler, T. and Krankenberg, H. (2008) Nitinol Stent Implantation in TASC A and B Superficial Femoral Artery Lesions: The Femoral Artery Conformexx Trial (FACT). Journal of Endovascular Therapy, 15, 390-398. https://doi.org/10.1583/08-2461.1

[95] Bosiers, M., Deloose, K., Callaert, J., Keirse, K., Virbst, J., Hendriks, J., Lauwers, P., D'Archambeau, O., Scheinert, D., Torsello, G. and Peeters, P. (2013) 4-French-Compatible Endovascular Material Is Safe and Effective in the Treatment of Femoropopliteal Occlusive Disease: Results of the 4-EVER Trial. Journal of Endovascular Therapy, 20, 746-756. https://doi.org/10.1583/13-4437MR.1

[96] Matsumura, J.S., Yamanouchi, D., Goldstein, J.A., Pollock, C.W., Bosiers, M., Schultz, G.A., Scheinert, D. and Rocha-Singh, K.J. (2013) The United States Study for Evaluating Endovascular Treatments of Lesions in the Superficial Femoral Artery and Proximal Popliteal By Using the Protégé Everflex NitInol Stent System II (DURABILITY II). Journal of Vascular Surgery, 58, 73-83.e1. https://doi.org/10.1016/j.jvs.2012.12.066

[97] Clever, Y., Peters, D., Calisse, J., et al. (2016) Novel Sirolimus Coated Balloon Catheter. In Vivo Evaluation in a Porcine Coronary Model. Circulation: Cardiovascular Interventions, 9, e03543. http://circinterventions.ahajournals.org

[98] Antoniou, G., Georgakarakos, E.I., Antoniou, S.A. and Georgiadis, G.S. (2014) Does Endovascular Treatment of Infra-Inguinal Arterial Disease with Drug-Eluting Stents Offer Better Results than Angioplasty with or without Bare Metal Stents? Interactive Cardiovascular and Thoracic Surgery, 19, 282-285. 
[99] Oransky, I. (2016) “Evidence-Based Medicine Has Been Hijacked:” A Confession from John Ioannidis. Retraction Watch.

[100] Ioannidis, J. (2005) Why Most Published Research Findings Are False. PLoS Medicine, 2, e124. https://doi.org/10.1371/journal.pmed.0020124

[101] Saxon, R.R., Dake, M.D., Volgelzang, R.L., Katzen, B. and Becker, G.J. (2008) Randomized, Multicenter Study Comparing Expanded Poly Tetrafluoroethylene-Covered Endoprothesis Placement with Percutaneous Transluminal Angioplasty in the treatment of Superficial Femoral Artery Occlusive Disease. Journal of Vascular and Interventional Radiology, 19, 823-832. https://doi.org/10.1016/j.jvir.2008.02.008

[102] Reijen, M.M.P.J., van Walraven, L.A., Fritschy, W.M., et al. (2017) 1-Year Results of a Multicenter Randomized Controlled Trial Comparing Heparin-Bonded Endoluminal to Femoropopliteal Bypass. JACC: Cardiovascular Interventions, 10, 2320-2331. https://doi.org/10.1016/j.jcin.2017.09.013

[103] Kinstner, C., Lammer, J., Willfort-Ehringer, A., Matzek, W., Gschwandtner, M., Javor, D., Funovics, M., Schoder, M., Koppensteiner, R., Loewe, C., Ristl, R. and Wolf, F. (2016) Paclitaxel-Eluting Balloon versus Standard Balloon Angioplasty in In-Stent Restenosis of the Superficial Femoral and Proximal Popliteal Artery. 1-year Results of the PACUBA Trial. JACC: Cardiovascular Interventions, 9, 1386-1392. https://doi.org/10.1016/j.jcin.2016.04.012

[104] Muller-Hulsbek, S., Keirse, K., Zeller, T., et al. (2016) Twelve-Month Results from the MAJESTIC Trial of the Eluvia Paclitaxel-Eluting Stent for Treatment of Obstructive Femoropopliteal Disease. Journal of Endovascular Therapy, 23, 701-707. https://doi.org/10.1177/1526602816650206

[105] Muller-Hulsbek, S., Keirse, K., Zeller, T., et al. (2017) Long-Term Results from the MAJESTIC Trial of the Eluvia Paclitaxel-Eluting Stent for Femoropopliteal Treatment: 3-Year Follow-Up. Cardiovascular and Interventional Radiology, 40, $1823-1838$

[106] Jongsma, H., van Mierlo-van den Broek, P., Imani, F., van den Heuvel, D., de Vries, J.-P. and Fioole, B. (2017) Randomized Comparison of Femoro-Popliteal Artery Drug-Eluting Balloons and Drug-Eluting-Stents (FOREST Trial): Study Protocol for a Randomised Controlled Trial. Journal of Vascular Surgery, 66, 1293-1298. https://doi.org/10.1016/j.jvs.2017.05.098

[107] Bausback, Y., Willfort-Ehringer, A., Sievert, H., et al. (2017) Six-Month Results from the initial Randomized Study of the Ranger Paclitaxel-Coated Balloon in the Femoropopliteal Segment. Journal of Endovascular Therapy, 24, 459-467.

[108] de Boer, S.W., van den Heuvel, D.A.F., de Vries-Werson, D.A.B., et al. (2017) Short-Term Results of the RAPID Randomized Trial of the Leg Flow Paclitaxel-Eluting Balloon with Supera Stenting vs Supera Stenting Alone for the Treatment of Intermediate and Long Superficial Femoral Artery Lesions. Journal of Endovascular Therapy, 24, 783-792.

[109] Schroeder, H., Werner, M., Meyer, D.-R., Reimer, P., Kruger, K., Jaff, M.R., Brodman, M., et al. (2017) Low-Dose Paclitaxel-Coated Versus Uncoated Percutaneous Transluminal Balloon Angioplasty for Femoro-popliteal Peripheral Artery Disease. Circulation, 135, 2227-2236. https://doi.org/10.1161/CIRCULATIONAHA.116.026493

[110] Gray, W.A., Keirse, K., Soga, Y., et al. (2018) A Polymer-Coated, Paclitaxel-Eluting Stent (Eluvia) versus a Polymer-Free, Paclitaxel-Coated Stent (Zilver PTX) for Endovascular Femororpopliteal Intervention (IMPERIAL): A Randomised, Non-Inferiority Trial. The Lancet, 392, 1541-1551. 


\section{Abbreviations}

PTA Percutaneous transluminal angioplasty

CLI Critical limb ischemia

ABSPI Ankle brachial systolic pulsatility index

IC Intermittent claudication

PAD Peripheral artery disease

DEB Drug eluting balloon

DES Drug eluting stent

SEP Standardized exercise program

RCT Randomised control trial 